\author{
Monika Maksim, Dominik Śliwicki
}

\title{
WYBRANE PROBLEMY ADRESOWANIA AKTYWNYCH POLITYK RYNKU PRACY W POLSCE
}

\begin{abstract}
Z a ry s tre ś c i. Prawidłowe adresowanie aktywnych polityk rynku pracy jest ważnym czynnikiem wpływającym na ich skuteczność w rozumieniu oddziaływania na zatrudnienie. Artykuł podejmuje próbę oceny poprawności adresowania aktywnej polityki rynku pracy zarówno w kontekście zapisów ustawowych, jak i aktualnych wyników analiz efektywności netto poszczególnych instrumentów. Analizie poddano podstawowe instrumenty aktywnej polityki rynku pracy, stosowane w Polsce w 2009 roku. Oceny adresowania aktywnych polityk rynku pracy dokonano na podstawie wyników estymacji szeregu modeli logitowych.
\end{abstract}

S ło w a k 1 u c z o w e: aktywna polityka rynku pracy, adresowanie, efektywność, bezrobocie.

K l a s y f i a c j a J L L: C 13, J 68.

\section{WSTĘP}

Aktywna polityka rynku pracy obejmuje zbiór strategii i działań podejmowanych bezpośrednio na rynku pracy, których celem jest przygotowanie bezrobotnych do ponownego ich włączania w proces pracy i zwiększanie szans na trwałe zatrudnienie. W Polsce w 2009 roku działaniem podstawowych form aktywizacji objęto 684,6 tysięcy osób, co stanowiło nieco ponad $35 \%$ ogółu bezrobotnych (MPiPS, 2010). Oznacza to, że wsparcie w ramach aktywnych polityk rynku pracy nie trafia do każdego bezrobotnego. Działania te mają charakter selektywny i są $\mathrm{z}$ reguły kierowane do znajdujących się w najtrudniejszym położeniu regionalnych rynków pracy i grup największego ryzyka.

W wielu krajach Unii Europejskiej, w tym również w Polsce, w sytuacji nadmiernego deficytu budżetowego i mało optymistycznych perspektyw wzrostu gospodarczego, istnieje coraz większa presja na racjonalizację wydatków, co skutkuje cięciem środków na cele społeczne, w tym również na walkę z bezro-

\footnotetext{
* Adres do korespondencji: Monika Maksim, Uniwersytet Mikołaja Kopernika, WNEiZ, ul. Gagarina 13a, 87-100 Toruń, e-mail: mouso@umk.pl; Dominik Śliwicki, Wyższa Szkoła Gospodarki w Bydgoszczy, ul. Garbary 2, 85-229 Bydgoszcz, e-mail: Dominik_Sliwicki@tlen.pl.
} 
bociem. Polityka rynku pracy ma charakter procykliczny, jej finansowanie cechuje strategia stop and go, powodująca pogorszenie jej efektywności w czasie złej sytuacji gospodarczej oraz pogłębienie nierównowagi na rynku pracy. Wobec tego ograniczaniu środków na aktywne polityki rynku pracy powinny towarzyszyć działania prowadzące do większej skuteczności podejmowanych programów zatrudnienia. Pewne możliwości daje poprawa adresowania aktywnych instrumentów polityki rynku pracy i ich rzetelna ewaluacja. Zatem obecnie powstaje dylemat czy aktywne programy, bez względu na prognozowane efekty, należy podporządkować potrzebom wybranych grup problemowych, czy raczej alokować środki na te instrumenty i kierować je do bezrobotnych, dla których prognozowane efekty brutto i netto będą relatywnie wysokie.

Formalne wytyczne dotyczące adresowania aktywnych programów powinny dawać odpowiedź na następujące pytania:

1. Jakie grupy bezrobotnych należy obejmować wsparciem w ramach aktywnej polityki rynku pracy w pierwszej kolejności?

2. Jakie instrumenty należy kierować do poszczególnych kategorii bezrobotnych?

Celem artykułu jest analiza i ocena poprawności adresowania aktywnych polityk rynku pracy w Polsce zarówno w kontekście zapisów ustawowych, jak i aktualnych wyników badania efektywności netto poszczególnych instrumentów. W opracowaniu podjęto również próbę oceny słuszności reguł adresowania programów zatrudnienia zawartych w Ustawie o promocji zatrudnienia i instytucjach rynku pracy (Dz.U. 2004, Nr 99, poz.1001 z późn.zm.)

\section{KONCEPCJE ADRESOWANIA AKTYWNYCH POLITYK RYNKU PRACY}

W polityce rynku pracy ścierają się dwie koncepcje adresowania aktywnych programów zatrudnienia. $\mathrm{Z}$ jednej strony mówi się o konieczności podporządkowania aktywnych instrumentów polityki rynku pracy potrzebom wybranych grup problemowych. Takie podejście, które określić można jako solidarnościowe, oznacza, że aktywne instrumenty, bez względu na prognozowane efekty, powinny być w pierwszej kolejności kierowane do bezrobotnych w najtrudniejszym położeniu, którzy bez odpowiedniego wsparcia $\mathrm{w}$ ramach aktywnych polityk rynku pracy nie są w stanie podjać zatrudnienia na konkurencyjnym rynku pracy ${ }^{1}$. Do grup problemowych na rynku pracy zalicza się młodzież, kobiety, osoby o niskich kwalifikacjach lub bez kwalifikacji zawodowych, osoby starsze, długookresowo bezrobotnych. Dość powszechnie jednak występuje dylemat, którą grupę bezrobotnych należy wspierać w staraniach o pracę w pierwszej kolejności i na aktywizację której kategorii należy przeznaczyć najwięcej środków.

\footnotetext{
${ }^{1}$ Problematykę kierowania do bezrobotnych wsparcia $\mathrm{w}$ ramach aktywnych polityk rynku pracy podejmuje również Kryńska (2009) w raporcie z badań dotyczącym flexicurity w Polsce.
} 
Z drugiej strony w sytuacji wysokiego deficytu budżetowego i ograniczonych środków na finansowanie aktywnych polityk rynku pracy w niektórych krajach Unii Europejskiej coraz bardziej na znaczeniu zyskuje proefektywnościowa koncepcja adresowania aktywnych programów zatrudnienia, zakładająca kierowanie instrumentów do grup bezrobotnych, dla których prognozowana efektywność zatrudnieniowa brutto i netto będzie kształtować się na relatywnie wysokim poziomie. Oznacza to, że jednym z głównych kryteriów decydujących o zakwalifikowaniu się do określonego programu jest indywidualna ocena potencjalnych szans na uzyskanie zatrudnienia po jego zakończeniu ${ }^{2}$. Takie rozwiązanie jest na przykład stosowane w Niemczech, gdzie od 2003 roku finansowane są tylko takie programy podnoszenia kwalifikacji, dla których według prognozy efekt zatrudnieniowy brutto wynosi co najmniej 70\% (Błędowski, 2008).

Jak pokazują wyniki badań ewaluacyjnych prowadzonych w krajach Unii Europejskiej (Martin, Grubb, 2001; Bergeman, van der Berg, 2007; Biewen i inni, 2007) oddziaływanie aktywnych instrumentów polityki rynku pracy nie jest identyczne w stosunku do różnych kategorii bezrobotnych zróżnicowanych pod względem płci, wieku, poziomu wykształcenia, stażu pracy, czy czasu trwania bezrobocia. Okazuje się, że niektóre programy bardziej pomagają kobietom, bezrobotnej młodzieży inne zaś bezrobotnym długotrwale czy osobom bez kwalifikacji. Bardzo ważną kwestią jest więc prawidłowe określenie rodzaju programu przynoszącego najlepsze efekty dla konkretnej grupy bezrobotnych, $\mathrm{z}$ ang. targeting. W tej sytuacji pomocne okazują się narzędzia do ewaluacji ex ante, które pozwalają oszacować prognozowany efekt zatrudnieniowy netto dla bezrobotnych skierowanych do różnych programów.

Specjaliści od ewaluacji podkreślają, że zastosowanie w praktyce zarówno podejścia solidarnościowego, jak i proefektywnościowego może zakłócać prawidłowe oddziaływanie aktywnych polityk rynku pracy. W przypadku, gdy programy adresowane są do bezrobotnych ze szczególnymi problemami, słabo rokujących na rynku pracy, występują efekty kwaszenia, z ang. souring (Trzciński, 2009), co z kolei powoduje, że zaobserwowane efekty po programie są niższe niż przeciętne oczekiwane efekty dla całej populacji bezrobotnych. W ten sposób można thumaczyć nieskuteczność robót publicznych czy prac społecznie użytecznych, programów, do których trafiają przeważnie bezrobotni cechujący się bardzo niską zdolnością do podjęcia zatrudnienia. W sytuacji odwrotnej, czyli kiedy aktywne programy są kierowane do bezrobotnych, dla których prawdopodobieństwo podjęcia pracy po programie jest relatywnie wysokie, powstają efekty spijania śmietanki, z ang. creaming, co oznacza, że osiągane efekty są wyższe niż przeciętne oczekiwane efekty dla całej populacji bezrobotnych.

\footnotetext{
${ }^{2}$ Podejście to powoduje prawdopodobnie skupienie się na krótko- i średniookresowo bezrobotnych, co może skutkować pogłębieniem długookresowego bezrobocia.
} 


\section{FORMALNE ZASADY ADRESOWANIA AKTYWNYCH POLITYK RYNKU PRACY W POLSCE}

W polskiej polityce rynku pracy praktykowane jest raczej podejście solidarnościowe. W Krajowym Planie Działań na rzecz Zatrudnienia na lata 2009-2011 zapisano ${ }^{3}$, że aktywne instrumenty polityki rynku pracy powinny trafiać do osób najbardziej potrzebujących wsparcia na rynku pracy, a nie takich, które najłatwiej jest aktywizować. Natomiast podażowo zorientowane instrumenty polityki rynku pracy, tj. szkolenia zawodowe, staże i przygotowanie zawodowe należy kierować przede wszystkim do osób o największej luce kompetencyjnej, słabo wykształconych oraz posiadających zawody i umiejętności, na które nie ma zapotrzebowania na rynku pracy. W dokumencie zwrócono również uwagę na konieczność intensyfikacji działań w zakresie aktywizacji ludzi starszych.

Ustawa o promocji zatrudnienia i instytucjach rynku pracy w artykule 49. (Dz.U. 2004, Nr 99, poz. 1001 z późn. zm.) definiuje grupy osób w szczególnej sytuacji, w stosunku do których przewidziany jest specjalny, szerszy zestaw instrumentów, niedostępny dla pozostałych bezrobotnych. Grupy te obejmują:

- bezrobotnych do 25. roku życia,

- bezrobotnych po zakończeniu realizacji kontraktu socjalnego,

- bezrobotne kobiety, które nie podjęły zatrudnienia po urodzeniu dziecka,

- bezrobotnych powyżej 50. roku życia,

- bezrobotnych bez kwalifikacji zawodowych, bez doświadczenia zawodowego lub bez wykształcenia średniego,

- bezrobotnych samotnie wychowujących co najmniej jedno dziecko do 18 . roku życia,

- bezrobotnych, którzy po odbyciu kary pozbawienia wolności nie podjęli zatrudnienia,

- bezrobotnych długotrwale.

Po pierwsze, trzeba zauważyć, że grupy podwyższonego ryzyka zostały określone w ustawie w sposób arbitralny, tymczasem grupy te mogą kształtować się nieco inaczej na lokalnych rynkach pracy. Po drugie, okazuje się, że osoby w szczególnej sytuacji na rynku pracy stanowią znacznie ponad połowę, a nawet do $90 \%$ ogółu bezrobotnych. Oznacza to, że z szerszej oferty usług i instrumentów polityki rynku pracy może korzystać większość zarejestrowanych bezrobotnych. Doświadczenia międzynarodowe pokazują, że aktywne programy zatrudnienia nie powinny być adresowane do tak szeroko zakrojonych grup docelowych, ponieważ są one $\mathrm{z}$ reguly silnie zróżnicowane wewnętrznie. Tak skonstruowane zapisy ustawowe nie do końca sprzyjają prawidłowemu adresowaniu i lepszej efektywności programów zatrudnienia.

\footnotetext{
${ }^{3}$ Ogólne wytyczne dotyczące adresowania aktywnej polityki rynku pracy w latach 2009 -2011 zostały sformułowane w Krajowym Planie Działań na rzecz Zatrudnienia na lata 2009-2011. http://www.mpips.gov.pl
} 
W przypadku programów służących podnoszeniu kwalifikacji, w tym przede wszystkim szkoleń, brakuje jasnych zasad obejmowania poszczególnych kategorii bezrobotnych tą formą wsparcia. Zapisy ustawowe są na tyle ogólne, że obecnie ze szkoleń skorzystać może praktycznie każdy bezrobotny. Nie prowadzi to do wysokiej skuteczności podażowo zorientowanych instrumentów polityki rynku pracy.

W sposobie postępowania pracowników publicznych służb zatrudnienia można jednak zauważyć pewne symptomy, które mogą świadczyć o proefektywnościowym stylu adresowania aktywnych programów rynku pracy. Dotyczy to na przykład szkolen zawodowych organizowanych w trybie indywidualnym. Okazuje się, że chociaż z formalnego punktu widzenia do uzyskania przez bezrobotnego skierowania na szkolenie konieczne jest jedynie uzasadnienie celowości odbycia określonego kursu, urzędnicy bardzo często wymagają dokumentu uprawdopodabniającego zatrudnienie. W podobny sposób jest wymuszana efektywność zatrudnieniowa staży. Służby zatrudnienia starają się kierować bezrobotnych do odbycia stażu u pracodawców, którzy często po zakończeniu programu oferują byłym stażystom zatrudnienie.

\section{OCENA ADRESOWANIA AKTYWNYCH POLITYK RYNKU PRACY W POLSCE}

Do oceny poprawności adresowania aktywnych polityk rynku pracy wykorzystano szereg dwumianowych modeli logitowych ${ }^{4}$, w których zmienna objaśniana przyjmuje wartość 0 lub 1 według następującej zależności:

$-y=1$, gdy bezrobotny otrzymał propozycję uczestnictwa $\mathrm{w}$ określonym programie,

$-y=0, \mathrm{w}$ przeciwnym przypadku.

Badaniu poddano podstawowe instrumenty aktywnej polityki rynku pracy, stosowane w Polsce w 2009 roku, takie jak: szkolenia zawodowe, staże, prace interwencyjne, prace społecznie użyteczne, roboty publiczne i dotacje na rozpoczęcie działalności gospodarczej. Empiryczną podstawą analizy były dane indywidualne o osobach bezrobotnych uczestniczących i nieuczestniczących w aktywnych programach rynku pracy, które pozyskano z systemu informacyjnego publicznych służb zatrudnienia Syriusz. Dane do badania zostały zebrane w sześciu powiatach wylosowanych spośród wyodrębnionych w procesie hierarchicznego grupowania grup powiatów reprezentujących określony typ gospodarki i stan na rynku pracy. Były to powiaty: miasto Torun z grupy dużych ośrodków miejskich, powiat tyski z grupy powiatów uprzemysłowionych, miasto Radom reprezentujące powiaty przemysłowe o przestarzałej strukturze gospodarczej, powiat wąbrzeski z grupy powiatów rolniczo-przemysłowych, powiat giżycki z grupy powiatów rolniczych z funkcją turystyczną i powiat biłgo-

\footnotetext{
${ }^{4}$ Szersze informacje na temat modeli logitowych można znaleźć w Gruszczyński (2010), Mikroekonometria. Modele i metody analizy danych indywidualnych.
} 
rajski z grupy powiatów tradycyjnych rolniczych. W sumie oszacowano siedem modeli logitowych, jeden objaśniający prawdopodobieństwo partycypacji w dowolnym aktywnym programie zatrudnienia i sześć określających prawdopodobieństwo zakwalifikowania się do konkretnego programu aktywnej polityki rynku pracy. Zmienne nieistotne statystycznie eliminowano w modelach metodą a posteriori. Przyjęto poziom istotności $\alpha=0,05$.

W badaniu posłużono się zmiennymi objaśniającymi o charakterze jakościowym, które są określane jako zmienne binarne. Przyjęte do modeli zmienne obejmowały cechy społeczno-demograficzne, takie jak: płeć, wiek; cechy charakteryzujące kapitał ludzki bezrobotnych, tj.: wykształcenie, doświadczenie zawodowe mierzone stażem pracy, oraz cechy wskazujące na charakter bezrobocia badanych, tj.: posiadanie prawa do zasiłku, długość okresu pozostawania bez pracy oraz liczbę rejestracji.

Analizy wyników estymacji modeli logitowych dokonano na podstawie ilorazów szans. W przypadku modelu pierwszego okazuje się, że największe prawdopodobieństwo uczestnictwa w dowolnym aktywnym programie zatrudnienia dotyczyło:

- kobiet,

- osób w wieku do 25 lat,

- osób z wykształceniem wyższym i średnim ogólnokształcącym,

- zarówno z krótkim, jak i dłuższym stażem pracy, nieprzekraczającym dwudziestu lat,

- osób pozostających bez pracy nie dłużej niż sześć miesięcy,

- bezrobotnych nieposiadających prawa do zasiłku,

- rejestrowanych w urzędzie jeden raz po 01.01 .2008 roku.

Propozycje udziału w szkoleniach zawodowych najczęściej trafiały do mężczyzn oraz osób będących w wieku od 25 do 35 lat. Szkoleniami najbardziej zainteresowane były osoby legitymujące się wykształceniem średnim ogólnokształcącym, średnim zawodowym oraz wyższym. Najwyższe szanse udziału w szkoleniach miały osoby pozostające bez pracy nie dłużej niż sześć miesięcy, nieposiadające prawa do zasiłku i zarejestrowane tylko jeden raz po 01.01.2008 roku.

Oferta odbycia stażu kierowana była przede wszystkim do kobiet oraz osób do 25 roku życia. Największe zainteresowanie tym programem występowało w grupie bezrobotnych $\mathrm{z}$ wykształceniem wyższym, średnim zawodowym i ogólnokształcącym. Propozycje udziału w stażu przedstawiano najczęściej bezrobotnym bez stażu pracy i z bardzo krótkim stażem pracy do pięciu lat, ale również osobom ze stosunkowo długim stażem pracy liczącym od dwudziestu do trzydziestu lat. Największe prawdopodobieństwo odbycia stażu dotyczyło bezrobotnych pozostających bez pracy nie dłużej niż trzy miesiące, nieposiadających prawa do zasiłku i zarejestrowanych w systemie ewidencji tylko jeden raz po 01.01.2008 roku. 
Tabela 1. Wyniki estymacji modeli logitowych objaśniających prawdopodobieństwo zakwalifikowania się do konkretnego aktywnego programu rynku pracy

\begin{tabular}{|c|c|c|c|c|c|c|}
\hline Zmienna & $\begin{array}{c}\text { Model } 1 \\
\text { (Szkolenia) }\end{array}$ & $\begin{array}{l}\text { Model } 2 \\
\text { (Staże) }\end{array}$ & $\begin{array}{c}\text { Model } 3 \\
\text { (Prace inter- } \\
\text { wencyjne) }\end{array}$ & $\begin{array}{c}\text { Model } 4 \\
\text { (Prace społecz- } \\
\text { nie użyteczne) }\end{array}$ & $\begin{array}{l}\text { Model 5 } \\
\text { (Roboty } \\
\text { publiczne) }\end{array}$ & $\begin{array}{l}\text { Model } 6 \\
\text { Dotacje }\end{array}$ \\
\hline PŁEĆ & 1,8158 & 0,3939 & n.s. & 0,5021 & 1,6436 & 2,7096 \\
\hline WIEK 1 (do 25 lat) & 1,8590 & 3,7346 & 0,2748 & 0,0218 & 0,1185 & n.s. \\
\hline WIEK 2 (25 - 35 lat) & 2,1111 & 1,7500 & 0,4921 & 0,1112 & 0,1836 & 2,7096 \\
\hline WIEK 3 (35 - 45 lat) & 2,0428 & 1,3189 & 0,5945 & 0,2744 & 0,3162 & 2,4617 \\
\hline WIEK 4 (45 - 55 lat) & 1,7456 & n.s. & n.s. & 0,6561 & 0,7420 & 2,4945 \\
\hline $\begin{array}{c}\text { WYKSZ } 2 \\
\text { (zasadnicze zawodowe) }\end{array}$ & 1,2529 & 2,4165 & n.s. & 0,7388 & 2,7434 & 1,7023 \\
\hline $\begin{array}{c}\text { WYKSZ } 3 \\
\text { (średnie zawodowe) }\end{array}$ & 2,1503 & 3,3660 & 0,7586 & 0,2678 & n.s. & 2,9712 \\
\hline $\begin{array}{c}\text { WYKSZ 4 } \\
\text { (średnie ogólnokształcące) }\end{array}$ & 2,3633 & 3,8701 & n.s. & 0,3763 & n.s. & 3,4592 \\
\hline WYKSZ 5 (wyższe) & 2,0483 & 6,0242 & n.s. & 0,0983 & n.s. & 4,3920 \\
\hline STAŻP 1 (do 5 lat) & n.s & 1,5210 & n.s. & 7,6105 & 4,0261 & 2,4262 \\
\hline STAŻP $2(5-10)$ & n.s & n.s. & n.s. & 6,0159 & 3,1703 & 3,5819 \\
\hline STAŻP 3 (10-20) & 1,2087 & 1,3728 & n.s. & 5,2194 & 4,3790 & 2,8584 \\
\hline STAŻP 4 (20-30) & n.s. & 1,4848 & 1,3628 & 2,7832 & 3,2652 & 2,7464 \\
\hline ZASIŁEK & 0,7129 & 0,1030 & 0,2828 & 0,0453 & n.s. & 0,4107 \\
\hline OKRESB 1 (do 1 miesiąca) & 171,2664 & 439,0837 & 6,1625 & 3,4707 & n.s. & 23,7723 \\
\hline OKRESB $2(1-3)$ & 168,9918 & 241,5581 & 3,3603 & 1,4360 & n.s. & 113,3255 \\
\hline OKRESB $3(3-6)$ & 118,4475 & 97,0591 & 2,0409 & 1,5272 & n.s. & 122,5624 \\
\hline OKRESB 4 (6-12) & 68,7035 & 51,3950 & n.s. & n.s. & n.s. & 53,5128 \\
\hline OKRESB 5 (12-24) & 48,5367 & 49,9279 & 1,8621 & 3,2834 & n.s. & 33,7723 \\
\hline $\operatorname{LR} 1(0-1)$ & 1,7191 & 8,1231 & 1,2311 & 2,2951 & 1,6923 & 15,19735 \\
\hline LR 2 (2-3) & n.s. & 3,6790 & n.s. & n.s. & n.s. & 5,3335 \\
\hline LR 3(4-5) & n.s. & n.s. & n.s. & n.s & n.s. & n.s. \\
\hline Liczba obserwacij & 76849 & 75518 & 75320 & 75486 & 75341 & 75930 \\
\hline R-kwadrat McFaddena & 0,0571 & 0,2746 & 0,0663 & 0,2156 & 0,1017 & 0,1081 \\
\hline $\begin{array}{c}\text { Trafność prognozy } \\
\text { (ogółem) }\end{array}$ & $97,4 \%$ & $94,2 \%$ & $99.9 \%$ & $99,1 \%$ & $99,3 \%$ & $98,6 \%$ \\
\hline
\end{tabular}

W tabeli przedstawiono otrzymane wartości ilorazów szans, n.s. - zmienna nieistotna statystycznie.

Źródło: obliczenia własne.

Największe szanse udziału $w$ pracach interwencyjnych miały osoby w wieku 55 lat i więcej, posiadające niskie wykształcenie (gimnazjalne lub podstawowe), ze stosunkowo długim stażem pracy liczącym od dwudziestu do trzydziestu lat. Jednocześnie program ten kierowany był przede wszystkim do krótkookresowo bezrobotnych pozostających w rejestrach nie dłużej niż sześć miesięcy oraz nieposiadających prawa do zasiłku. Płeć nie miała istotnego statystycznie wpływu na prawdopodobieństwo uczestnictwa w tym programie zatrudnienia.

Największe prawdopodobieństwo uzyskania propozycji uczestnictwa w robotach publicznych dotyczyło mężczyzn oraz osób w wieku 55 lat i więcej. Programy te trafiały przeważnie do bezrobotnych o niskim poziomie wykształ- 
cenia, ze stażem pracy od dziesięciu do dwudziestu lat. Bez znaczenia okazał się czas trwania bezrobocia i fakt posiadania prawa do zasiłku.

Do prac społecznie użytecznych kierowano przede wszystkim kobiety, osoby starsze w wieku 55 lat i więcej, legitymujące się wykształceniem gimnazjalnym i podstawowym, ze stosunkowo krótkim stażem pracy nieprzekraczającym dziesięciu lat. Największe prawdopodobieństwo uzyskania skierowania do prac społecznie użytecznych miały osoby zarówno pozostające bez pracy nie dłużej niż jeden miesiąc, jak i powyżej dwunastu miesięcy.

O dotacje na rozpoczęcie działalności gospodarczej ubiegali się przeważnie mężczyźni, osoby w wieku 25-35 lat. Największe zainteresowanie udziałem $\mathrm{w}$ tym programie stwierdzono $\mathrm{w}$ grupie bezrobotnych $\mathrm{z}$ wykształceniem wyższym i średnim ogólnokształcącym, ze stażem pracy liczącym od pięciu do dziesięciu lat. Największe szanse na uzyskanie dotacji na rozpoczęcie działalności gospodarczej miały osoby krótkookresowo bezrobotne, pozostające bez pracy nie dłużej niż sześć miesięcy, zarejestrowane tylko jeden raz po 01.01.2008 r.

\section{ADRESOWANIE AKTYWNYCH POLITYK RYNKU PRACY A ICH EFEKTYWNOŚĆ}

Biorąc pod uwagę zapisy ustawowe i uzyskane wyniki badań można stwierdzić, że aktywne programy zatrudnienia, w tym szczególnie podażowo zorientowane instrumenty polityki rynku pracy nie do końca były poprawnie adresowane. Ze szkoleń częściej korzystali mężczyźni oraz osoby młode do 35 roku życia. Poza tym udział w szkoleniu proponowano osobom stosunkowo dobrze wykształconym. Tymczasem najnowsze badania efektywności aktywnej polityki rynku pracy w Polsce ${ }^{5}$ wskazują, że szkolenia są skuteczną formą aktywizacji mężczyzn, bezrobotnych zarówno w młodym, jak i starszym wieku oraz generują najwyższe efekty zatrudnieniowe netto w stosunku do osób legitymujących się wykształceniem zasadniczym zawodowym i gimnazjalnym. Ze względu na występowanie relatywnie wysokich efektów jałowej straty w przypadku szkolenia osób o względnie wysokich kwalifikacjach, zaleca się zachowanie większej rozwagi i ostrożności przy kierowaniu tego rodzaju wsparcia do tej kategorii bezrobotnych.

Wysokimi szansami uczestnictwa w stażu zawodowym charakteryzowali się bezrobotni zarówno bez lub z krótkim stażem, jak i ze stażem pracy przekraczającym dwadzieścia lat. Trzeba zauważyć, że od nowelizacji ustawy z 2008 roku, która weszła w życie 1 lutego 2009 roku (Dz. U. 2009, nr 6, poz. 33) staże mo-

\footnotetext{
${ }^{5}$ Badania efektywności aktywnej polityki rynku pracy w Polsce przeprowadzono $\mathrm{w}$ ramach projektu POKL pn. Monitorowanie efektywności polityki rynku pracy - opracowanie metodologii badania efektywności podstawowych aktywnych form przeciwdziałania bezrobociu realizowanego przez Centrum Rozwoju Zasobów Ludzkich. Dokładne informacje na temat podstaw metodologicznych badania oraz szczegółowe wyniki można znaleźć w Wiśniewski, Zawadzki (2011), Efektywność polityki rynku pracy w Polsce.
} 
gą być kierowane do wszystkich bezrobotnych znajdujących się szczególnej sytuacji na rynku pracy. Posunięcie to nie do końca było korzystne, gdyż jak pokazują analizy efektywności pozytywne efekty netto staży odnotowano wyłącznie w grupie bezrobotnych bez i z krótkim doświadczeniem zawodowym. Staże przynosiły pozytywne rezultaty w stosunku do bezrobotnych mężczyzn, natomiast częściej do tego programu kierowane były kobiety. Programy stażowe nie sprawdzily się również $\mathrm{w}$ odniesieniu do bezrobotnych relatywnie dobrze wykształconych, grupy najczęściej korzystającej z tej formy pomocy.

Tabela 2. Efekty netto aktywnych polityk rynku pracy w Polsce w przekroju wybranych cech społeczno-demograficznych (w pkt. proc.)

\begin{tabular}{|c|c|c|c|c|c|c|}
\hline \multirow[b]{2}{*}{ Wyszczególnienie } & \multicolumn{6}{|c|}{ Rodzaj aktywnego programu } \\
\hline & Szkolenia & Staże & $\begin{array}{l}\text { Prace inter- } \\
\text { wencyjne }\end{array}$ & $\begin{array}{l}\text { Prace społecz- } \\
\text { nie użyteczne }\end{array}$ & $\begin{array}{c}\text { Roboty } \\
\text { publiczne }\end{array}$ & Dotacje \\
\hline \multicolumn{7}{|c|}{ Płeć: } \\
\hline mężczyźni & 14,2 & 5,9 & 14,3 & $-6,9$ & $-0,6$ & 65,7 \\
\hline kobiety & 0,8 & $-0,9$ & 6,6 & $-8,4$ & $-8,7$ & 59,8 \\
\hline \multicolumn{7}{|c|}{ Wiek w latach: } \\
\hline do 25 & 11,4 & 0,6 & 3,2 & $-5,8$ & 11,0 & 71,8 \\
\hline $25--35$ & 11,2 & 3,2 & 18,9 & $-7,6$ & $-0,5$ & 60,3 \\
\hline $35--45$ & 9,9 & $-4,8$ & 9,1 & $-9,3$ & $-15,7$ & 60,4 \\
\hline $45--55$ & 4,4 & $-5,5$ & 7,2 & $-8,8$ & $-4,5$ & 67,2 \\
\hline powyżej 55 & 16,2 & 8,9 & 9,1 & $-9,7$ & 14,3 & 75,0 \\
\hline \multicolumn{7}{|c|}{ Wykształcenie: } \\
\hline $\begin{array}{l}\text { gimnazjalne } \\
\text { i poniżej }\end{array}$ & 10,1 & 7,6 & 12,3 & $-6,1$ & $-0,2$ & 78,4 \\
\hline $\begin{array}{l}\text { zasadnicze } \\
\text { zawodowe }\end{array}$ & 13,9 & 3,4 & 0,6 & $-10,7$ & $-8,9$ & 67,9 \\
\hline $\begin{array}{l}\text { średnie } \\
\text { zawodowe }\end{array}$ & 9,0 & $-1,6$ & 10,8 & $-17,1$ & $-6,2$ & 61,9 \\
\hline \multicolumn{7}{|c|}{ Wykształcenie c.d.: } \\
\hline $\begin{array}{l}\text { średnie ogólno- } \\
\text { kształcace }\end{array}$ & 5,9 & 2,4 & $-10,6$ & $-5,0$ & $-1,6$ & 68,3 \\
\hline wyższe & 7,4 & $-6,5$ & 32,0 & $-56,2$ & 22,8 & 53,2 \\
\hline \multicolumn{7}{|c|}{ Staż pracy w latach: } \\
\hline do 5 & 10,4 & 2,8 & 15,5 & $-5,2$ & 4,4 & 67,8 \\
\hline $5--10$ & 11,1 & $-0,9$ & 9,4 & $-14,5$ & $-13,7$ & 59,0 \\
\hline $10--20$ & 10,3 & $-4,0$ & $-1,2$ & $-20,9$ & $-11,7$ & 50,5 \\
\hline 20--30 & 8,2 & $-14,9$ & 2,0 & $-21,8$ & $-0,9$ & 56,4 \\
\hline powyżej 30 & 12,5 & $-20,8$ & 1,5 & $-17,8$ & 6,8 & 59,3 \\
\hline \multicolumn{7}{|c|}{ Czas trwania bezrobocia w miesiącach: } \\
\hline $1--3$ & 14,7 & 2,2 & 17,5 & $-3,5$ & 6,0 & 64,8 \\
\hline $3--6$ & 13,6 & 3,0 & 13,9 & $-6,5$ & $-0,3$ & 66,2 \\
\hline 6--12 & 3,0 & 3,8 & 14,1 & $-11,3$ & 4,3 & 61,7 \\
\hline powyżej 12 & 5,1 & $-6,8$ & $-1,3$ & $-12,3$ & $-9,0$ & 61,0 \\
\hline
\end{tabular}

Kursywą zapisano wartości nieistotne statystycznie. Przyjęto poziom istotności $\alpha=0,1$.

Źródło: badania empiryczne.

Uczestnictwo w pracach społecznie użytecznych, pracach interwencyjnych, robotach publicznych, zgodnie z zapisami ustawowymi proponowano najczę- 
ściej bezrobotnym znajdującym się $\mathrm{w}$ najtrudniejszym położeniu, tj.: osobom $\mathrm{w}$ wieku powyżej 55 lat, z niskim poziomem wykształcenia, pozostającym bez pracy powyżej dwunastu miesięcy. Niestety instrumenty te nie służyły w sposób bezpośredni wyjściu z bezrobocia wskazanych grup bezrobotnych, efekt netto prac społecznie użytecznych i robót publicznych był ujemny lub nieistotny statystycznie we wszystkich badanych grupach bezrobotnych.

Trzeba jednak podkreślić, że celem prac społecznie użytecznych jest przede wszystkim przezwyciężenie bezradności i bierności bezrobotnych, pobudzenie motywacji do pracy i jej poszukiwania oraz uzyskanie niewielkiego dochodu. Roboty publiczne poprzez krótkotrwałe zatrudnienie zapewniają wsparcie dochodowe bezrobotnym w najtrudniejszym położeniu. Ocena tych programów wyłącznie na podstawie efektów zatrudnieniowych nie wydaje się do końca zasadna, miarą bowiem sukcesu tego rodzaju wsparcia nie jest wyłącznie podjęcie pracy. Specjaliści od rynku pracy uważają, że nie należy przypisywać jednemu programowi zbyt wielu celów i oddzielnie realizować działania zmierzające do wzrostu zatrudnialności i przedsięwzięcia ukierunkowane na poprawę materialnej sytuacji bezrobotnych (Maksim, Wiśniewski, 2009). Z drugiej strony aktywizacja osób wywodzących się z grup największego ryzyka jest trudna i czasochłonna, wymaga zastosowania nie jednego, a raczej specjalnego zestawu wzajemnie uzupełniających się instrumentów, na przykład łączenia poradnictwa zawodowego, szkoleń z formami subsydiowanego zatrudnienia.

Dotacje na działalność gospodarczą trafiały przeważnie do bezrobotnych dobrze rokujących na rynku pracy. Efekty zatrudnieniowe dotacji były relatywnie wysokie bez względu na płeć, wiek, wykształcenie, staż pracy i czas trwania bezrobocia. Trzeba w tym miejscu zaznaczyć, że efektywność dotacji na podjęcie działalności gospodarczej została prawdopodobnie przeszacowana ze względu na sposób pomiaru stosowany przez publiczne służby zatrudnienia, skutkujący znacznym zawyżaniem efektów brutto tych instrumentów. Ta forma aktywizacji jest jednak dość kosztowna i w dłuższej perspektywie czasowej generuje przeważnie pozytywne efekty zatrudnieniowe w stosunku do bezrobotnych posiadających względnie wysokie kwalifikacje, bardziej skłonnych do ryzyka i przedsiębiorczych. Możliwości wykorzystania tego rodzaju wsparcia wobec długotrwale bezrobotnych są ograniczone.

\section{PODSUMOWANIE}

Konkludując, z jednej strony stwierdza się, że aktywne polityki rynku pracy nie do końca były adresowane zgodnie $\mathrm{z}$ regulacjami ustawowymi. $\mathrm{Z}$ drugiej strony natomiast kierowanie się przy doborze bezrobotnych do programów zapisami zamieszczonymi w ustawie nie zawsze sprzyjało osiaganiu wysokiej skuteczności zatrudnieniowej. Wydaje się, że konieczne jest umożliwienie węższego i jednocześnie bardziej dokładnego definiowania grup w szczególnej sytuacji na poszczególnych lokalnych rynkach pracy oraz zastosowanie przy selekcji uczestników programów koncepcji typu mix, tzn. łączącej podejście 
solidarnościowe z efektywnościowym. Ważne jest, aby poszczególne programy trafiały zgodnie z zaleceniami polityki rynku pracy do osób najbardziej potrzebujących, ale jednocześnie dla których uczestnictwo w programie będzie realnym czynnikiem zwiększającym szanse na trwałe zatrudnienie (tzn. prognozowane efekty netto będą relatywnie wysokie). Oznacza to konieczność prowadzenia systematycznej ewaluacji ex ante i ex post aktywnych polityk rynku pracy. Dobrym rozwiązaniem może być również zastosowanie technik profilowania bezrobotnych (Wojdyło-Preisner, 2009), za pomocą których identyfikuje się grupy bezrobotnych w trudnej sytuacji na rynku pracy, a następnie oferuje zindywidualizowane wsparcie.

\section{LITERATURA}

Bergeman A., van der Berg G. (2007), Acitve Labour Market Policy Effects for Woman in Europe - a survey, IFAU Working Paper 3, Uppsala, 1-20.

Biewen M., Fitzenberger B., Osikominu A., Walker M (2007), Which Program for Whom? Evidence on the Effectiveness of Public Sponsored Training Programs in Germany, IZA Discussion Paper Series, Discussion Paper 2885, Bonn, 1-64.

Błędowski P., red. (2008), Efektywność usług i instrumentów rynku pracy stużacych podnoszeniu kwalifikacji bezrobotnych $w$ Polsce $i w$ wybranych krajach Unii Europejskiej, MPiPS, Warszawa.

Gruszczyński M., red. (2010), Mikroekonometria. Modele i metody analizy danych indywidualnych, Wolters Kluwer Polska, Warszawa.

Kryńska E. (2009), Aktywna polityka rynku pracy, [w:] Kryńska E. (red.), Flexicurity w Polsce, diagnoza i rekomendacje. Raport końcowy z badań, MPiPS, Warszawa, 17-35.

Maksim M., Wiśniewski Z. (2009), Polityka rynku pracy wobec aktywizacji zawodowej osób starszych, [w:] Wiśniewski Z. (red.), Determinanty aktywności zawodowej ludzi starszych, TNOiK, Toruń.

Martin J.P., Grubb D. (2001), What works and for whom: A review of OECD countries' experiences with active labour market policies, „Swedish Economic Policy Review”, 8, 9-56.

MPiPS (2009), Krajowy Plan Działań na rzecz Zatrudnienia na lata 2009-2011, Warszawa, http://mpips.gov.pl (10.09.2010).

MPiPS (2010), Efektywność podstawowych form aktywizacji zawodowej realizowanych w ramach programów na rzecz promocji zatrudnienia, tagodzenia skutków bezrobocia i aktywizacji zawodowej w 2009 roku, Warszawa.

Trzciński R. (2009), Wykorzystanie techniki propensity score matching $w$ badaniach ewaluacyjnych, PARP, Warszawa.

Ustawa z 20 kwietnia 2004 r. o promocji zatrudnienia i instytucjach rynku pracy, Dz. U. 2004, nr 99, poz.1001 (z późn. zm.).

Ustawa z 19 grudnia 2008 r. o zmianie ustawy o promocji zatrudnienia i instytucjach rynku pracy oraz o zmianie niektórych ustaw, Dz. U. 2008, nr 6, poz. 33.

Wiśniewski Z, Zawadzki K., red. (2011), Efektywność polityki rynku pracy w Polsce, WUP, UMK, Torun.

Wojdyło-Preisner M. (2009), Profilowanie bezrobotnych jako metoda przeciwdziałania dlugookresowemu bezrobociu, UMK, Toruń. 


\section{SELECTED PROBLEMS OF TARGETING ACTIVE LABOUR MARKET POLICIES IN POLAND}

A b s tract. Well targeted active labour market policies create better prospects for achieving higher net employment effects. This article attempts to analyse targeting of active labour market policies in the context of regulations contained in the act on employment promotion and labour market institutions, and current evaluation findings. In case of high budget deficit it comes to a dilemma whether to aim active measures, regardless of their results to the most disadvantaged groups in the labour market or to allocate more money on the most effective programs and target them to the unemployed for whom ex ante evaluated net employment outcomes are relatively high. The paper analyses basic active labour market policies, that have been in place in Poland in 2009. To assess program targeting logistic regression was applied.

K e y w o r d s: active labour market policy, targeting, effectiveness, unemployment. 